UDC: 634.13-152.632(497.7)

COBISS.SR-ID: 211609612

Original research paper

Acta Agriculturae Serbica, Vol. XIX, 37 (2014); 47-60

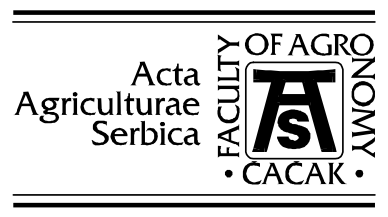

\title{
Traditional pear varietes in the west region of Republic of Macedonia
}

\author{
Ana Selamovska \\ Department of Fruit Growing, Institute of Agriculture, Ss. Cyril and Methodius \\ University in Skopje, Blvd. 16 Makedonska Brigada 3A, Skopje1000, R. of \\ Macedonia

\section{Elizabeta Miskoska - Milevska \\ Olga Najdenovska}

Faculty of Agricultural Sciences and Food, Ss. Cyril and Methodius University in Skopje,

\section{Daniela Dimovska}

Centre for Applied Research and Permanent Education in Agriculture - Skopje Blvd. Aleksandar Makedonski, Skopje1000, R. of Macedonia

\begin{abstract}
In this article, we present the results of the examination of the morphological, phenological and chemical characteristics of fruits of 9 traditional pear varieties that are typical for the west region of Macedonia ('Carigradsko avche', 'Evropsko avche', 'Vodenka', 'Sherbetka', 'Sinec', 'Letna kajkushka', 'Trupnjak', 'Tiranka' and 'Zimska
\end{abstract}

Received: 20. 06. / Accepted: 02. 10. 2014. 
kajkushka'). According to the ripening time, the pears 'Carigradsko avche', 'Evropsko avche', 'Sherbetka', 'Sinec' and 'Letna kajkushka' are summer pear varieties, the pear 'Vodenka' is an autumn pear variety and the pears 'Trupnjak', 'Tiranka' and 'Zimska kajkushka' are winter pear varieties. Statistically significant differences among the examined pear varieties for all fruit characteristics are found. The biggest fruits are characteristic of the pears 'Vodenka', 'Tiranka' and 'Trupnjak'. All pear varieties, excluding the pears 'Evropsko avche', 'Vodenka' and 'Zimska kajkushka', have long fruit stalks. Medium to high quantity of seeds are found in the fruits of the pears 'Letna kajkushka', 'Zimska kajkushka' and 'Carigradsko avche'. The highest value of soluble dry matter is found in the pear 'Vodenka' and 'Zimska kajkushka'. The highest content of total sugar in the fruits ( $15 \%$ or more) is detected in the varieties 'Zimska kajkushka', 'Evropsko avche', 'Tiranka' and 'Vodenka'. The best flavor and juiciest mesocarp is characteristic of the pear 'Vodenka'.

Key words: genetic resources; pear varieties; traditional.

\section{Introduction}

In the past, a plenty of domestic pear varieties such as 'Carigradsko avche', 'Evropsko avche', 'Arapka', 'Ekshikuti', 'Ekshija', 'Ekserka', 'Zimorka', 'Vodenka', 'Karamanka', 'Kurtizaim', 'Letna kajkushka', 'Zimska kajkushka', 'Lerinka', 'Maslarka', 'Sari armut', 'Tatlija', 'Tiranka', 'Shalganka' etc., existed on the territory of the Republic of Macedonia (Avramovski et al. 2005). But by the introduction of new pear varieties or the replacement of local varieties with new varieties from abroad, the genetic diversity decreased significantly. The traditional pear varieties were neglected and destroyed. Namely, the traditional pear varieties became rare in Macedonia. Today, these varieties are commonly found in abandoned areas and hilly-mountainous regions in the country, where extensive agriculture is still used (Selamovska and Nikolić, 2012).

Realizing this situation, it was obvious that there is a need for studying traditional pear varieties, their determination and selection of quality varieties in relation to the researched characteristics, dissemination and conservation. The study was part of the scientific projects Study of Autochthonous Pear Varieties in the Republic of Macedonia (2009) and Research of Autochthonous Pear Varieties in the Republic of Macedonia (2011), supported by the Ministry of Agriculture, Forestry and Water Economy of Macedonia. The research analyses were done in collaboration with professionals from the Agency for Individual Agriculture Development from Tetovo, Gostivar, Kichevo and Debar. 


\section{Materials and methods}

For an appropriate selection of pear varieties for certain soil and climatic conditions to be done, it is necessary to know the phenological and fruit characteristics of the varieties, their respond to different soil and climate conditions, their sensitivity and resistance to abiotic and biotic factors, their time of ripening, fruit yield etc. Starting from this, the aim of this study was the determination of: phenological characteristics (flowering and ripening time), fruit characteristics (fruit mass - $\mathrm{g}$, dimensions of fruit $-\mathrm{cm}$, fruit hardness $\mathrm{g} / \mathrm{cm}^{2}$, length of fruit stalk - $\mathrm{cm}$, number of seeds in a fruit, fruit color and taste and content of stone cells) and chemical characteristics of the fruit (soluble dry mater - $\%$, total sugar - $\%$ and total acids - $\%$ ). This research was a part of the scientific-research projects "Study of Autochthonous Pear Varieties in the Republic of Macedonia" which were funded by the Ministry of Agriculture, Forestry and Water Economy of Macedonia, during two years. The first year, the pear varieties were determined and labeled. The second year the researches activates were done.

A description of the variety was made by an IBPGR descriptor. The fruits were classified by mass and diameter. According to fruit mass, pear varieties are classified by Mratinić as: very small (to $25 \mathrm{~g}$ ), small (26-50 g), medium-small (51-100 g), medium (101-150 g), medium-large (151-200 g), large (201-300 g) and very large fruits (above $300 \mathrm{~g}$ ) (Mratinić, 2000). According to fruit diameter (Rubcov classification), small fruits have diameter to $5 \mathrm{~cm}$, medium-large fruits have diameter of 5.1-10 cm and large fruits have diameter of more than $10 \mathrm{~cm}$. According to the number of seeds in the fruit, pear varieties have very low quantity (0.1-1), low (1.1-3), medium (3.1-5) to high quantity of seeds (5.1-10) (Nyeki and Soltesz, 1998). According to the length of the fruit stalk, pear varieties have short stalk (to $2 \mathrm{~cm}$ ), medium-long $(2.1-3.5 \mathrm{~cm}$ ) and long stalk (more than $3.5 \mathrm{~cm}$ ).

The fruit firmness was measured with a FT02 penetrometer and the fruit mass was weighed on the Mettler analytical laboratory scale. The extraction of seeds was done manually and then the number of filled (healthy) seeds per fruit was counted. The soluble dry matter were measured with Carl Zeiss JenaDDR/713457 refractometer. Also, the total sugar were directly measured with the refractometer. The total acids were determined by a standard method of titration $(\mathrm{NaOH})$. The received data were statistically processed using analysis of variance (ANOVA).

The object of this study was 9 traditional pear varieties ('Carigradsko avche', 'Evropsko avche', 'Vodenka', 'Sherbetka', 'Sinec', 'Letna kajkushka', 'Trupnjak', 'Tiranka' and 'Zimska kajkushka'), that are typical for west part of Macedonia i.e. the regions of Tetovo, Gostivar, Kichevo and Debar (Figure 1-9). 


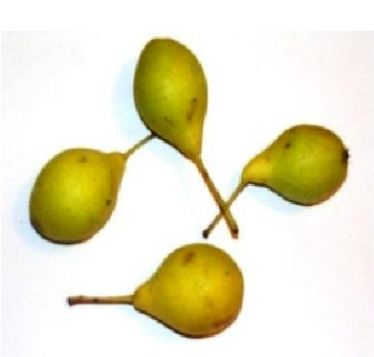

Fig. 1. Pear 'Carigradsko avche'

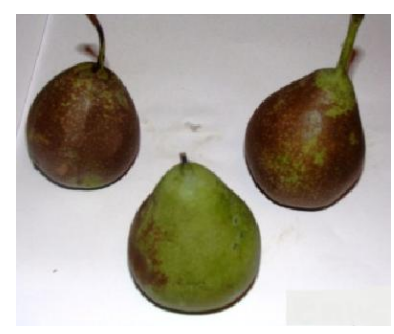

Fig. 4. Pear 'Sinec'

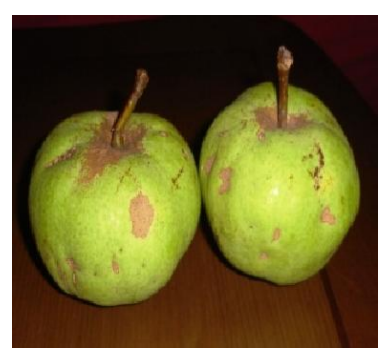

Fig. 7. Pear 'Trupnjak'

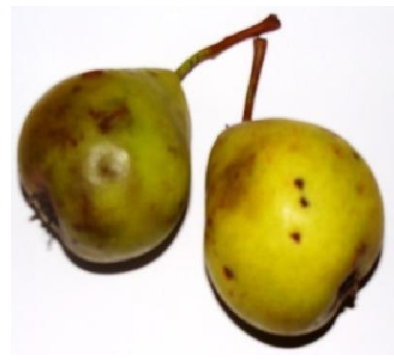

Fig. 2. Pear 'Evropsko avche'

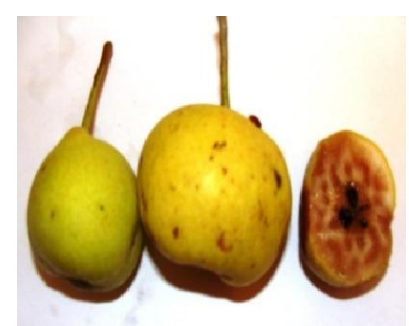

Fig. 5. Pear 'Letna kajkushka'

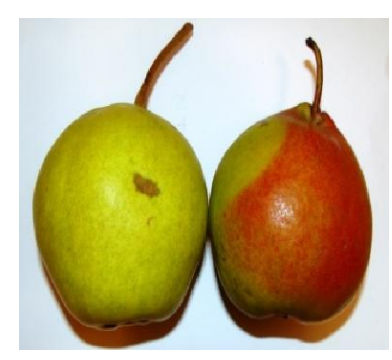

Fig. 8. Pear 'Tiranka'

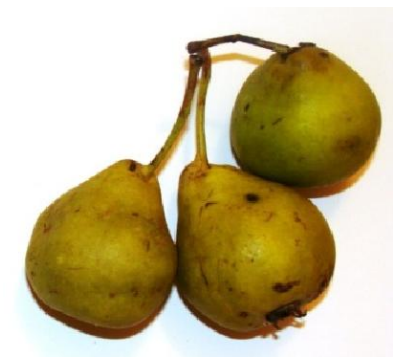

Fig. 3. Pear 'Sherbetka'

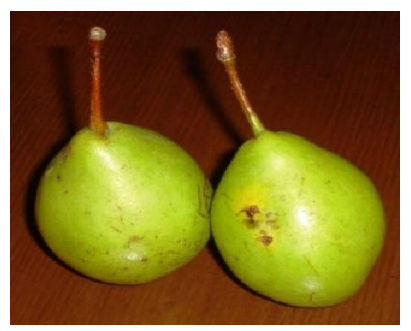

Fig. 6. Pear 'Vodenka'

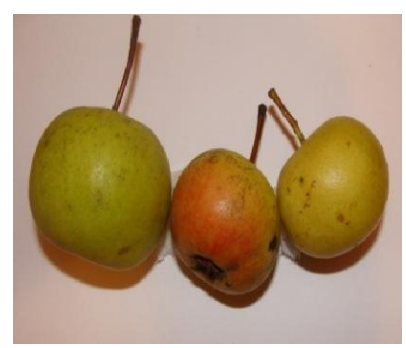

Fig. 9. Pear 'Zimska kajkushka'

The regions of Tetovo, Gostivar, Kichevo and Debar belong to hot continental climate-vegetation-soil region and are situated on altitude of $600-900 \mathrm{~m}$. These regions present $24.4 \%$ of the territory of Macedonia. An average year temperature in these regions is in the range of $9.6^{\circ} \mathrm{C}-11.8$ ${ }^{\circ} \mathrm{C}$ (average $10.9{ }^{\circ} \mathrm{C}$ ). The sum of average year temperatures is $3975{ }^{\circ} \mathrm{C}$. The number of summer days is 87 . The average year falls is $700 \mathrm{~mm}$ and the average year drought index is 33.5 (Filipovski et al. 1996). In this climate-vegetation-soil region chromic luvisol on saprolite is present, but albicluvisol is the dominant soil type (WRB, Classification 2006). The soil 
temperature on depth of $20 \mathrm{~cm}$ is in range of $11.1^{\circ} \mathrm{C}-12.8^{\circ} \mathrm{C}$, and on depth of $50 \mathrm{~cm}$ goes from $12.3{ }^{\circ} \mathrm{C}$ to $13.1{ }^{\circ} \mathrm{C}$ (Filipovski et al. 1996).

\section{Results and Discussion}

The researched pear varieties are adapted on the local conditions and they are naturally resistant to different biotic and abiotic factors. Their characteristics are vitality and long-lasting (more than 100 years old). The obtained results of the research are presented in the Table 1, Table 2 and Table 3.

Table 1. Vigorous and phenological characteristics of researched traditional pear varieties in the west region of Macedonia

\begin{tabular}{|c|c|c|c|}
\hline Variety & Vigorous trees & Flowering time & Ripening time \\
\hline $\begin{array}{l}\text { Carigradsko } \\
\text { avche' }^{\prime}\end{array}$ & $\begin{array}{l}\text { vigorous well- } \\
\text { developed and } \\
\text { branchy trees }\end{array}$ & $\begin{array}{c}\text { the second decade } \\
\text { of April }\end{array}$ & $\begin{array}{l}\text { the first half of } \\
\text { July }\end{array}$ \\
\hline Evropsko avche' & middle & $\begin{array}{c}\text { the second decade } \\
\text { of April }\end{array}$ & the middle of July \\
\hline Sherbetka' & $\begin{array}{l}\text { vigorous well- } \\
\text { developed and } \\
\text { branchy trees }\end{array}$ & $\begin{array}{l}\text { the first decade of } \\
\text { April }\end{array}$ & $\begin{array}{c}\text { the middle of } \\
\text { August }\end{array}$ \\
\hline Sinec' & $\begin{array}{l}\text { vigorous well- } \\
\text { developed and } \\
\text { branchy trees }\end{array}$ & $\begin{array}{l}\text { the middle of } \\
\text { April }\end{array}$ & the end of August \\
\hline Letna kajkushka' & middle & $\begin{array}{l}\text { the middle of } \\
\text { April }\end{array}$ & the end of August \\
\hline Vodenka' & $\begin{array}{l}\text { vigorous well- } \\
\text { developed and } \\
\text { branchy trees }\end{array}$ & $\begin{array}{c}\text { the second decade } \\
\text { of April }\end{array}$ & $\begin{array}{l}\text { the end of } \\
\text { September }\end{array}$ \\
\hline Tiranka' & middle & $\begin{array}{c}\text { the second decade } \\
\text { of April }\end{array}$ & $\begin{array}{l}\text { at the end of } \\
\text { October and at the } \\
\text { beginning of } \\
\text { November }\end{array}$ \\
\hline Trupnjak' & $\begin{array}{l}\text { vigorous well- } \\
\text { developed and } \\
\text { branchy trees }\end{array}$ & $\begin{array}{c}\text { the second decade } \\
\text { of April }\end{array}$ & $\begin{array}{l}\text { act the end of } \\
\text { beginning of } \\
\text { November } \\
\text { at the end of }\end{array}$ \\
\hline $\begin{array}{l}\text { Zimska } \\
\text { kajkushka' }\end{array}$ & middle & $\begin{array}{c}\text { the third decade } \\
\text { of April }\end{array}$ & $\begin{array}{c}\text { October and at the } \\
\text { beginning of } \\
\text { November }\end{array}$ \\
\hline
\end{tabular}


Table 2. Morphological characteristics of researched traditional pear varieties in the west region of Macedonia

\begin{tabular}{|c|c|c|c|c|c|c|}
\hline Variety & $\begin{array}{c}\text { Fruit } \\
\text { mass (g) }\end{array}$ & $\begin{array}{l}\text { Fruit } \\
\text { length } \\
\text { (cm) }\end{array}$ & $\begin{array}{l}\text { Fruit } \\
\text { width } \\
\text { (cm) }\end{array}$ & $\begin{array}{c}\text { Length } \\
\text { of } \\
\text { fruit } \\
\text { stalk } \\
\text { (cm) } \\
\end{array}$ & $\begin{array}{l}\text { Number } \\
\text { of seeds } \\
\text { in fruit }\end{array}$ & $\begin{array}{c}\text { Fruit } \\
\text { firmness } \\
\left(\mathrm{g} / \mathrm{cm}^{2}\right)\end{array}$ \\
\hline $\begin{array}{l}\text { Carigradsko } \\
\text { avche' }\end{array}$ & 13.8 & 3.1 & 3.1 & 3.9 & 5.1 & 1276.7 \\
\hline $\begin{array}{l}\text { Evropsko } \\
\text { avche' }\end{array}$ & 48.9 & 4.63 & 4.5 & 3.5 & 1.9 & 1352.3 \\
\hline Sherbetka' & 60.6 & 5.3 & 4.9 & 4.1 & 0.5 & 1713.3 \\
\hline Sinec' & 60.8 & 5.6 & 4.6 & 3.9 & 1.2 & 1470 \\
\hline $\begin{array}{l}\text { Letna } \\
\text { kajkushka' }\end{array}$ & 23.7 & 3.1 & 3.7 & 4.4 & 3.7 & 1200 \\
\hline Vodenka' & 152.3 & 7.4 & 6.5 & 2.8 & 2.7 & 1221.7 \\
\hline Tiranka' & 214.1 & 7.9 & 7.8 & 4.2 & 2.1 & 1275 \\
\hline Trupnjak' & 120.8 & 5.2 & 5.6 & 3.9 & 2 & 1620 \\
\hline $\begin{array}{l}\text { Zimska } \\
\text { kajkushka' }\end{array}$ & 45.3 & 3.8 & 4.4 & 2.9 & 5 & 1301.3 \\
\hline Average & 82.2 & 5.1 & 5 & 3.7 & 2.7 & 1381.1 \\
\hline $\mathbf{F}$ & 315.3519 & 484.7367 & 486.3217 & 24.2226 & 41.80233 & 11.81709 \\
\hline p-value & 2E-129 & $7.5 \mathrm{E}-152$ & $5 \mathrm{E}-152$ & $1.04 \mathrm{E}-27$ & $1.26 \mathrm{E}-42$ & $2.35 \mathrm{E}-14$ \\
\hline F critic & 1.973975 & 1.973975 & 1.973975 & 1.973975 & 1.973975 & 1.973975 \\
\hline
\end{tabular}

According to the morphological characteristics, these pear varieties form different vigorous trees. The pears 'Tiranka', 'Zimska kajkushka', 'Evropsko avche' and 'Letna kajkushka' form middle vigorous trees, and the other varieties 'Carigradsko avche', 'Sherbetka', 'Sinec', 'Vodenka' and 'Trupnjak' form vigorous, well-developed and branchy trees (Table 1).

The researched pear varieties flower in April, from the first decade to the end of April, depending on their genotype. The variety 'Sherbetka' flowers at the earliest (in the first decade of April). Next are the pears 'Carigradsko avche', 'Evropsko avche', 'Trupnjak', 'Vodenka' and 'Tiranka' (in the second decade of April). The varieties 'Sinec' and 'Letna kajkushka' flower in the middle of April. The pear 'Zimska kajkushka' flowers at the latest (in the third decade of April) (Table 1). 
Table 3. Chemical content of analyzed pear varieties

\begin{tabular}{lccc}
\hline Variety & $\begin{array}{c}\text { Soluble dry } \\
\text { matter } \mathbf{( \% )}\end{array}$ & Total acids (\%) & $\begin{array}{c}\text { Total sugar } \\
(\mathbf{\%})\end{array}$ \\
\hline Carigradsko avche' & 16.2 & 0.39 & 14 \\
Evropsko avche' & 16.7 & 0.21 & 15 \\
Sherbetka' & 12.8 & 0.32 & 11.7 \\
Sinec' $^{\prime}$ & 14.9 & 0.35 & 13.8 \\
Letna kajkushka' & 14.3 & 0.16 & 14 \\
Vodenka' & 18 & 0.25 & 15.8 \\
Tiranka' & 15.4 & 0.27 & 15.2 \\
Trupnjak' & 15.6 & 0.15 & 13 \\
Zimska kajkushka' & 18.3 & 0.23 & 16.9 \\
Average & 15.8 & 0.26 & 14.4 \\
F & 13224 & 2951.958 & 231.2213 \\
p-value & 0 & $4.2 \mathrm{E}-251$ & $8.9 \mathrm{E}-114$ \\
\hline F critic & 1.973975 & 1.973975 & 1.973975 \\
\hline
\end{tabular}

The pear 'Carigradsko avche' ripens the earliest (in the first half of July), followed by the pear 'Evropsko avche' (in the middle of July), the variety 'Sherbetka' (in the first half of August), the pears 'Sinec' and 'Letna kajkushka' (at the end of August), the variety "Vodenka" (at the end of September). The fruits from the varieties 'Trupnjak', 'Tiranka' and 'Zimska kajkushka' ripen the last (at the end of October and at the beginning of November) and they are stored until March-April for complete ripening and consumption (Table 1).

The variety 'Tiranka' has the largest fruit. The medium-large fruit is characteristic for the pears 'Trupnjak' and 'Vodenka'. The varieties 'Sherbetka' and 'Sinec' form medium-small fruits. The small to very mall fruits are produced by 'Evropsko avche', 'Zimska kajkushka', 'Carigradsko avche' and 'Letna kajkushka'. As presented in Table 2, the analysed pear varieties have long fruit stalks except the varieties 'Vodenka', 'Evropsko avche' and 'Zimska kajkushka' which have medium-long fruit stalks.

The lowest quantity of seeds was detected in the variety 'Sherbetka'. The pears 'Letna kajkushka', 'Zimska kajkushka' and 'Carigradsko avche' produce medium to high quantity of seeds in the fruits.

The color of fruit mesocarp is whitish ('Carigradsko avche', 'Sherbetka', 'Sinec', 'Trupnjak' and 'Tiranka'), yellowish-white ('Letna kajkushka' and 'Zimska kajkushka') to yellowish ('Evropsko avche' and 'Vodenka'). The low quantity of stone cells is present in the pears 'Carigradsko avche', 'Sherbetka' and 'Vodenka'. The highest value of stone cells is found in fruits from the varieties 'Sinec', 'Trupnjak' and 'Zimska kajkushka'. When the fruits of the analyzed pears ripen, the mesocarp rots. 
The average content of soluble dry matter, total acids and total sugar in the analyzed pear varieties is $15.8 \%, 0.26 \%$ and $14.4 \%$, respectively. As presented in the Table 3, the highest content of soluble dry matter is detected in the pears 'Vodenka' and 'Zimska kajkushka'. The high values of total sugar, $15 \%$ or more, are measured in the varieties 'Zimska kajkushka', 'Evropsko avche', 'Tiranka' and 'Vodenka'. The researched pear varieties have relatively high value of total acids.

The analyzed pear varieties are characterized as varieties with good and regular yield. The tree of the variety 'Tiranka' in the village Galate gives yield of one tone. The average yield the pears 'Carigradsko avche' and 'Vodenka' give is $200-300 \mathrm{~kg} /$ tree (Dimitrovski, 1974). According to Stančević (1983) and Niketić (1951), the varieties 'Zimska kajkushka' and 'Tiranka' are a super highyield varieties $(178.0 \mathrm{~kg} /$ tree i.e. $192.5 \mathrm{~kg} /$ tree or more than $30.000 \mathrm{~kg} / \mathrm{ha}$ ). These varieties exist in a purely natural environment, and at same time they are healthy organic food and they find suitable place in the organic agricultural production.

The researched regions belong to same climate-vegetation-soil region and they have similar climate. Because of this, there is no difference among the analyzed pear varieties from these regions in the flowering and ripening time.

According to Dimitrovski (1974) the variety 'Vodenka' is an early-flowering pear variety. The pear 'Evropsko avche' is characterized as early-intermediate variety, but the pear 'Carigradsko avche' is a late- intermediate variety. The variety 'Tiranka' is an early-flowering pear variety (Gjurgjević and Šoškić 1968) to late-intermediate variety (Dimitrovski, 1974). The pear 'Zimska kajkushka' is late-flowering pear variety (Gjurgjević and Šoškić 1968).

Depending of the repining time, the varieties 'Carigradsko avche', 'Evropsko avche', 'Sherbetka', 'Sinec' and 'Letna kajkushka' are summer pear varieties. The pear 'Vodenka' is an autumn variety, the varieties 'Trupnjak', 'Tiranka' and 'Zimska kajkushka' are winter varieties.

Different varieties have different time of ripening, depending of the climatic conditions and the altitude. In the region of Skopje, situated on low altitude, the fruits of the variety 'Carigradsko avche' ripen early, at the beginning of July, during the orthodox holiday Petrovden. In the region of Resen, this variety ripens later. The fruits of the variety 'Evropsko avche' ripen the earliest in the regions of Gevgelija, Skopje and Veles, but the latest in the regions of Debar and Resen (Selamovska et al., 2013). The fruits of 'Sinec' ripen the earliest in the regions of the Skopje and Kriva Palanka, and the latest in the Debar region. The variety 'Letna kajkushka' ripens the earliest in the region of Gevgelija and the latest in the Resen region. The pear 'Vodenka' ripens in the first half of September in the region of Skopje and Kumanovo, at the end of September in the Debar region and its surroundings, and at the beginning of October in Resen, Berovo, Pehchevo and Kriva Palanka (Selamovska, 2013). 
The fruit size is a variety characteristic and it depends on the ecological conditions, the type of pollination, etc. (Vujanić-Varga, 1985). Significant differences are found in this characteristic among the analyzed pear varieties (Table 2). According to the Rubcov classification, the varieties 'Carigradsko avche', 'Evropsko avche', 'Sherbetka', 'Sinec', 'Letna kajkushka' and 'Zimska kajkushka' have small fruits. The pears 'Vodenka', 'Tiranka' and 'Trupnjak' form medium-large fruits. The obtained data are in agreement with the results from the previous studies. The pear 'Carigradsko avche' forms very small to small fruits with average mass of $36 \mathrm{~g}$, fruit length of $5.3 \mathrm{~cm}$ and fruit width of 4 cm (Dimitrovski, 1974; Selamovska, 2013). The variety 'Evropsko avche' has fruits with mass of $63 \mathrm{~g}$, fruit length of $6 \mathrm{~cm}$ and fruit width of $4.7 \mathrm{~cm}$ (Selamovska, 2013). The pear 'Letna kajkushka' forms small fruits with mass of $28.1 \mathrm{~g}$, fruit length of $3.2 \mathrm{~cm}$ and fruit width of $3.7 \mathrm{~cm}$ (Selamovska, 2013). The pear 'Vodenka' has medium-small fruits with average mass of $87.55 \mathrm{~g}$ (Mratinić, 2000) to medium-large fruits with average mass of 180-300 g (Niketić, 1951; Dimitrovski, 1974, Milutinović et al., 1998, Avramovski at al., 2005, Milutinović et al,. 2005, Selamovska, 2013). In dry conditions, the fruit productivity is alternative. The fruits are smaller and with lowest quality with puckery taste and highest value of stone cells (Dimitrovski, 1974). According to Selamovska (2013) the variety 'Sherbetka' forms medium-small fruits with average fruit mass of $60.6 \mathrm{~g}$, fruit length of $5.3 \mathrm{~cm}$ and fruit width of $4.9 \mathrm{~cm}$. The pear 'Sinec' has medium-small fruits with average fruit mass of $53.7 \mathrm{~g}$, fruit length of $5.3 \mathrm{~cm}$ and fruit width of $4.4 \mathrm{~cm}$. The variety 'Tiranka' has mediumlarge fruits with average fruit mass of $175.8 \mathrm{~g}$, fruit length of $7.1 \mathrm{~cm}$ and fruit width of $7.0 \mathrm{~cm}$. The pear 'Trupnjak' forms fruits with average fruit mass of $130.9 \mathrm{~g}$, fruit length of $5.7 \mathrm{~cm}$ and fruit width of $6.2 \mathrm{~cm}$. The larges fruits are measured in the regions of Skopje and Kriva Palanka (Selamovska, 2013). The fruits of the variety 'Zimska kajkushka' are small (Mratinić, 2000), with average fruit mass of $45.7 \mathrm{~g}$, fruit length of $3.7 \mathrm{~cm}$ and fruit width of $4.5 \mathrm{~cm}$ (Selamovska, 2013).

As presented in the Table 2, the detected differences in the length of fruit stalk among the analyzed pear varieties are statistically significant. The pears 'Vodenka', 'Evropsko avche' and 'Zimska kajkushka' have medium-long fruit stalks and the other pear varieties have long fruit stalks. The length of the fruit stalk is a positive characteristic for the variety's growing in windy and unsuitable conditions (Dimitrovski, 1974). According to Selamovska (2013) the variety 'Carigradsko avche' has long fruit stalks $(3.8 \mathrm{~cm})$, medium-thick, on oblique position. The pear 'Evropsko avche' has medium-thick and long fruit stalks (average $3.7 \mathrm{~cm}$ ) on lateral position. The average length of fruit stalk of the variety 'Sherbetka' is $4.1 \mathrm{~cm}$. The pear "Sinec' has medium-thin and long fruit stalks with average value of $4.4 \mathrm{~cm}$. The fruit stalk of the variety 'Letna kajkushka' is thick, medium-long, with average value of $3.1 \mathrm{~cm}$. The pear 
'Vodenka' has thin and long fruit stalk (average $3.5 \mathrm{~cm}$ ) and a little curve. The fruit stalk of the variety 'Trupnjak' is quite a thick, medium-long with average value of $3.3 \mathrm{~cm}$, on vertical position. The pear 'Tiranka' has a firm, curve and long fruit stalk, with average value of $4.4 \mathrm{~cm}$, while the variety 'Zimska kajkushka' has thin, medium-long $(3.0 \mathrm{~cm})$, vertical fruit stalk, situated on a low hole (Selamovska, 2013).

The content of seeds in a fruit speaks about the fertility of the genotype i.e. variety. The low value of seeds points to triploidy of the varieties (Dimitrovski, 1974) or tendency to partenocarpy (Nyeki et al., 1998). The analyzed varieties contain low quantity of seeds in the fruit (average 2.7). Significant differences are found in the number of seeds in the fruit, among the researched pear varieties (Table 2). According to Selamovska (2013), the variety 'Carigradsko avche' produces 2.7 seeds, the pear 'Evropska ache' contains 1.2 seeds, the variety 'Sherbetka' has 0.5 seeds, the pear 'Sinec' contains 1.0 seeds, the variety 'Letna kajkushka' has 4.4, the pear 'Vodenka' produces 1.5 seeds, the variety 'Trupnjak' has 2.0 seeds, the variety 'Tiranka' produces 2.8 seeds and the pear 'Zimska kajkushka' has 5.1 seeds.

The pear 'Trupnjak' is characterized by the firmest fruits and its name comes from this characteristic. Statistically significant differences are found in the fruit firmness among the analyzed pear varieties (Table 2).

Also, significant differences are found in the soluble dry matter, total acids and total sugar among the analyzed pear varieties (Table 3 ). The highest sugar index is characteristic of the varieties 'Evropska ache', 'Letna kajkushka' and 'Trupnjak'. But, if we take into consideration the other elements such as taste, fruit firmness, quality and juicy mesocarp, presence of aromatic components, tannins, stone cells etc., the best flavor and juicy mesocarp is characteristic of the pear 'Vodenka'. This variety has thin and soft exocarp. When the fruit is ripe, the fruit peel cracks and the juice leaks out as water. Its name comes from this characteristic. This cultivar is named "Sonlija" in the regions of Berovo and Pehchevo. Namely, the metaphoric meaning of the name "Sonlija" is nice like sun (Selamovska, 2013).

The lowest taste is characteristic of the pear 'Zimska kajkushka'. This variety has firm and granular mesocarp with puckery taste because of its high quantity of tannins (Dimitrovski, 1974). Because of this, this pear causes a feeling of choking during the eating. And this is a reason for its local name (gushodavka - meaning: something that makes you choke) in some areas. The other pear varieties have medium to good taste.

According to Selamovska (2013), the fruits of the variety 'Carigradsko avche' contain $19.8 \%$ total dry matter, $13.0 \%$ soluble dry matter, $11.7 \%$ total sugar and $0.39 \%$ total acids. The average fruit firmness is $1423.7 \mathrm{~g} / \mathrm{cm}^{2}$. It is mostly used for consumption when fresh. The fruits of the variety 'Evropsko avche' contain $14.1 \%$ average soluble dry matter, $13.6 \%$ total sugar and $0.28 \%$ 
total acids (Selamovska, 2013). This pear variety gives quality fruit, sensitive to manipulation and transport. It is suitable for fresh consumption, drying and making compote (Dimitrovski, 1974; Popov et al. 1983). The fruits of the variety 'Sherbetka' contain $12.8 \%$ soluble dry matter, $11.7 \%$ total sugar and $0.32 \%$ total acids (Selamovska, 2013). They are used for fresh consumption, drying and making compote.

According to Selamovska (2013), the fruits of the variety 'Sinec' contain $12.3 \%$ soluble dry matter, $12.0 \%$ total sugar and $0.32 \%$ total acids. They are used for making brandy in the Kriva Palanka region (Selamovska, 2013).

The pear 'Letna kajkushka' has $20.91 \%$ average total dry matter, $13.1 \%$ soluble dry matter, $14.2 \%$ total sugar and $0.20 \%$ total acids (Selamovska, 2013). Dimitrovski (1974) recommends this variety only for domestic usage.

The fruits of the variety 'Vodenka' contain $18.5 \%$ total dry matter, $15.4 \%$ soluble dry matter, $14.0 \%$ total sugar and $0.23 \%$ total acids (Selamovska 2013 ). According to Mratinić (2000) the fruits of the pear 'Vodenka' contain $19.5 \%$ dry matter, $0.17 \%$ total acids and $17.9 \%$ total sugar.

The fruits of the variety 'Trupnjak' have $15.5 \%$ soluble dry matter, $13.6 \%$ total sugar and $0.20 \%$ total acids (Selamovska, 2013). They are used for consumption and processing.

In the variety 'Tiranka' there are $23.0 \%$ total dry matter, $15.3 \%$ soluble dry matter, $14.2 \%$ total sugar and 0.27 total acids (Selamovska, 2013, Selamovska et al., 2012) measured. Its fruits are used for boiling, baking and in brine. In some areas in the east region of Macedonia, they are used for making brandy. These fruits look nice and have good quality. From the above mentioned, this variety deserves to be part of the pear production.

The fruits of the pear 'Zimska kajkushka' contain $19.7 \%$ total dry matter, $17.0 \%$ soluble dry matter, $15.5 \%$ total sugar and $0.24 \%$ total acids (Selamovska, 2013). These fruits were used for drying and making tea, compote and brine in the past. According to Mratinic (2000) the fruits of 'Zimska kajkushka' contain $15.5 \%$ dry matter, $0.19 \%$ total acids and $14.36 \%$ total sugar.

\section{Conclusion}

The varieties 'Carigradsko avche', 'Evropsko avche', 'Vodenka', 'Sherbetka', 'Sinec', 'Letna kajkushka', 'Trupnjak', 'Tiranka' and 'Zimska kajkushka' exist in the west region of Macedonia. According to the flowering time, the variety 'Sherbetka' flowers the earliest, the next are the pears 'Carigradsko avche', 'Evropsko avche', 'Trupnjak', 'Vodenka' and 'Tiranka' . The varieties 'Sinec' and 'Letna kajkushka' flower in the middle of April. The pear 'Zimska kajkushka' flowers the latest . 
According to the ripening time, the pears 'Carigradsko avche', 'Evropsko avche', 'Sherbetka', 'Sinec' and 'Letna kajkushka' are classified as summer pear varieties, the pear 'Vodenka' is an autumn pear variety and the pears 'Trupnjak', 'Tiranka' and 'Zimska kajkushka' are winter pear varieties.

Statistically significant differences among the researched pear varieties for all fruit characteristics were found. According to the Rubcov classification, the varieties 'Vodenka', 'Tiranka' and 'Trupnjak' form medium-large fruits. The other pear varieties have small fruits. All analyzed pear varieties have long fruit stalks except the varieties 'Vodenka', 'Evropsko avche' and 'Zimska kajkushka', which have medium-long fruit stalks. The lowest quantity of seeds is detected in the variety 'Sherbetka'. The pears 'Letna kajkushka', 'Zimska kajkushka' and 'Carigradsko avche' produce medium to high quantity of seeds in the fruits.

The average content of soluble dry matter, total acids and total sugar in the analyzed pear varieties is $15.8 \%, 0.26 \%$ and $14.4 \%$, respectively. The highest content of soluble dry matter was measured in the pears 'Vodenka' and 'Zimska kajkushka'. The highest value of total sugar is measured in the varieties 'Zimska kajkushka'. Also, the highest value of total sugar ( $15 \%$ or more) is detected in the fruits of 'Evropsko avche', 'Tiranka' and 'Vodenka'.

The best flavor and juicy mesocarp is characteristic of the pear 'Vodenka'. The lowest taste is characteristic of the pear 'Zimska kajkushka'. The other pear varieties have medium to good taste.

\section{References}

Avramovski O., Grupčev M., Sekulovski. J. (2005): Lets grafting future on old roots. GTZ, Coordinative Chamber of Prespa Park, ALLKOOP, Ohrid. (in Macedonian).

Dimitrovski T. (1974): Fruit growing, Pome fruit. Faculty of Agriculture, Skopje. (in Macedonian).

Filipovski Gj., Rizovski R., Ristevski P. (1996): Characteristics of climate-vegetative-soil zones (regions) in Republic of Macedonia. MASA, Skopje. (in Macedonian).

Gjurgjević I., Šoškić M. (1968): Survey of Research of Flowering on Some Pear Cultivars in Peć. Journal of Yugoslav Pomology, 3: 13-21. (in Serbian)

Milutinović M., Miletić R., Milutinović M., Novaković M. (2005): Pear Genetic Resources in West Serbia. Fruit growing, 39 (2): 149-154.

Milutinović M., Miletić R., Petrović R., Nikolić D., Milutinović M. (1998): Variability of autochthonous pear cultivars in Timocka Krajina (Serbia). Acta Horticulturae, 475: 105-110.

Mratinić E. (2000): Pear. Cooperative Book. Nolit. Belgrade. (in Serbian).

Niketić M. (1951): Fruit variety. Pear, Cydonia and Mespilus. Zadruzna knjiga. Belgrade. (in Serbian).

Nyeki J., Soltesz M. (1998): The variation of seed content of fruits in pear varieties, also as function of different conditions of fertilization, as open pollination, natural 
autogamy and allogamy. VII International symposium on pear growing, Talca, Chile. ISHS Acta Horticulturae. 475: 237-250.

Nyek J., Soltesz M., Ivancsics J. (1998): Natural tendency to parthenocarpy of pear varieties in Hungary. VII International symposium on pear growing, Talca, Chile. ISHS Acta Horticulturae, 475: 367-378.

Popov S., Angelov T., Georgievski V., Stoyanov A. (1983): Pomologia, Plovdiv. (in Bulgarian).

Selamovska A. (2013): Traditional pear varieties in Republic of Macedonia. Monograph, Alfa 94, Skopje. (in Macedonian).

Selamovska A., Karakashova Lj., Nikolić Z. (2012): Traditional winter pear varieties in Republic of Macedonia. Yearbook Ecology, health, work and sport, 379-383. (in Serbian).

Selamovska A., Miskoska - Milevska E., Najdenovska O. (2013): Genetic Resources of Traditional Pear Varieties in the Region of Skopje. Contributions, Section of Natural, Mathematical and Biotechnical Sciences (MASA), 34 (1-2): 93-100.

Selamovska A., Nikolić K. (2012): Traditional pear varieties in Republic of Macedonia. Yearbook Ecology, health, work and sport, 374-378. (in Serbian).

Stančević A. (1983): Dynamic of yield in 102 pear varieties in region of West Morava. Journal of Yugoslav Pomology, 17: 3-13. (in Serbian).

Vujanić-Varga D. (1985): Influence of Pollinators on Mesocarpic Cell Size in Pears. Journal of Yugoslav Pomology, 19: 97-102. (in Serbian). 


\title{
AUTOHTONE SORTE KRUŠKE ZAPADNOG REGIONA REPUBLIKE MAKEDONIJE
}

\author{
Ana Selamovska \\ Odeljenje za voćarstvo, Poljoprivredni institut, Ss. Ćirilo i Metodije Univerzitet \\ u Skoplju, Blvd. 16 Makedonska Brigada 3A, Skoplje 1000, R. Makedonija \\ Elizabeta Miskoska - Milevska \\ Olga Najdenovska \\ Fakultet poljoprivrednih i prehrambenih nauka, Ss. Ćirilo i Metodije Univerzitet \\ u Skoplju
}

\section{Daniela Dimovska}

Centar za primenjena ispitivanja i trajnu edukaciju u poljoprivredi-Skoplje, Blvd. Aleksandar Makedonski, Skoplje 1000, R. Makedonija

\section{Rezime}

U ovom radu, predstavljamo rezultate ispitivanja morfoloških, fenoloških i hemijskih karakteristika plodova 9 autohtonih sorti kruške koje su tipične za zapadni region Makedonije (Carigradsko avche', 'Evropsko avche', 'Vodenka', 'Sherbetka', 'Sinec', 'Letna kajkushka', 'Trupnjak', 'Tiranka' and 'Zimska kajkushka'). Prema vremenu zrenja, 'Carigradsko avche', 'Evropsko avche', 'Sherbetka', 'Sinec' and 'Letna kajkushka' se svrstavaju u letnje sorte krušaka, 'Vodenka' jesenja, a sorte 'Trupnjak', 'Tiranka' and 'Zimska kajkushka' zimske. Pronađene su statistički značajne razlike između sorti za sve karakteristike ploda. Najkrupnije plodove imale su sorte 'Vodenka', 'Tiranka' and 'Trupnjak'. Plodovi svih sorti osim 'Evropsko avche', 'Vodenka' and 'Zimska kajkushka' imaju duge peteljke. Srednje visoka količina semenki nalazi se u plodovima sorti 'Letna kajkushka', 'Zimska kajkushka' and 'Carigradsko avche'. Najveći sadržaj rastvorljivih suvih materija pronađen je kod 'Vodenka' and 'Zimska kajkushka'. Najveći sadržaj ukupnih šećera ( $15 \%$ i više) utvrđen je kod sorti 'Zimska kajkushka', 'Evropsko avche', 'Tiranka' and 'Vodenka'. Najbolji ukus i najsočniji mezokarp utvrđen je kod sorte 'Vodenka'.

Ključne reči: genetički resursi, sorte kruške, autohtono. 